Aloman 2018, 36(2), 9-20

Revista de Psicologia, Ciències de l'Eduació i de l’Esport

ISSN: $1138-3194$

(CFacultat de Psicologia, Ciències de l'Educació i de l'Esport Blanquerna

Universitat Ramon Llull

\title{
Research traditions in social sciences and their methodological rationales
}

\author{
Josep Gallifa
}

Ramon Llull University

Received: 4-9-2018

Accepted: 13-11-2018

\section{Research traditions in social sciences and their methodological rationales}

Summary. The aim of this article is to review and describe the most common research paradigms in social sciences in order to then use this knowledge to inform the choice of research methods. Paradigms are defined here as traditions generated by the diversity of ways of understanding reality and the associated beliefs about what knowledge is and how it can be created. Research traditions can be characterised by the coherence in the articulation of their ontology, epistemology and the corresponding methodologies. The traditions studied here are Logical Empiricism, Constructivism, Conceptualism (or Productive Science in the Aristotelian tradition), and Phenomenology. For each one, the corresponding methodologies are described, their rationales are presented and detailed and some methodological developments are explained, with a special focus on those most often used in Psychology and Education. Because the advancement of social sciences requires integrating findings into broader theoretical frameworks, the article argues in favour of the need to explicitly include paradigmatic and methodological rationales in the justification of the choice of research method. It is seen as a necessary step in establishing the relevance of research and to facilitate the integration of perspectives. The need for this awareness increases when the scientific community has diverse backgrounds and/or the scope of a field is wide or interdisciplinary. Additionally, integral approaches require the bringing together of research from a range of paradigms. In these cases, the explicit presenting of this rationale is a reasonable requirement to further ensure the quality of a piece of research.

Keywords: Research traditions; ontology; epistemology; methodology; logical empiricism; constructivism; Aristotle; productive science; phenomenology

\author{
Correspondence \\ Josep Gallifa \\ orcid.org/0000-0002-8272-3688 \\ Facultat de Psicologia, Ciències de l'Educació i Esport \\ Blanquerna \\ Universitat Ramon Llull \\ josepgr@blanquerna.url.edu
}




\section{Les tradicions d'investigació en ciències socials i les seves raons metodològiques}

Resum. L'objectiu d'aquest article és revisar i descriure els paradigmes d'investigació més freqüents en ciències socials per tal d'utilitzar aquest coneixement per a l'elecció dels mètodes d'investigació. Els paradigmes es defineixen aquí com a tradicions generades per la diversitat de maneres d'entendre la realitat i les creences associades sobre el que és el coneixement $i$ com es pot crear. Les tradicions d'investigació es poden caracteritzar per una coherent articulació de la seva ontologia, epistemologia i metodologies corresponents. Les tradicions estudiades aquí són l'empirisme lògic, el constructivisme, el conceptualisme (o la ciència productiva en la tradició aristotèlica), i la fenomenologia. Per a cadascuna, es descriuen les metodologies corresponents, es presenten i es detallen les seves raons i s'expliquen alguns desenvolupaments metodològics, amb un enfocament especial en els més utilitzats en Psicologia i Educació. Com que l'avanç de les ciències socials requereix la integració de troballes en marcs teòrics més amplis, l'article defensa la necessitat d'incloure explícitament fonamentacions paradigmàtiques i metodològiques en la justificació de l'elecció del mètode d'investigació. Es considera un pas necessari per establir la rellevància de la recerca i facilitar la integració de les perspectives. La necessitat d'aquesta consciència augmenta quan la comunitat científica té diversos orígens $i$ I o l'abast d'un camp és ampli o interdisciplinari. A més, els enfocaments integrals requereixen la unió de recerques provinents de diversos paradigmes. En aquests casos, la presentació d'aquesta fonamentació és un requisit raonable per garantir encara més la qualitat d'una investigació.

Paraules clau: tradicions d'investigació; ontologia; epistemologia; metodologia; empirisme lògic; constructivisme; Aristòtil; ciència productiva; fenomenologia 


\section{Introduction}

The aim of a scientific journal is to serve research groups or individuals by publishing their original research or theoretical advances. The result of this process is the gradual shaping of a scientific community that is committed to research practices within the scope of a certain field of human scientific endeavor. When it comes to the scientific community involved in social science disciplines, a wide range of methods has to be welcomed in light of today's diversity of potential methods. Nevertheless, in order to properly share theoretical advances, it is necessary to develop a collective awareness of certain ontological, epistemological and methodological matters. Otherwise, the necessary critical discussion would be too poor and weak to support collective progress. When, in addition, the scientific community comes from different backgrounds, and/or the scope of a given field is wide, the need to share unified languages increases. In fact, it is absolutely imperative to critical discourse. Accurate ontological, epistemological and methodological languages are crucial to the comprehension and integration of findings from diverse research traditions.

Meanwhile, when it comes to a single piece of research and the need to communicate it with the greatest possible quality standards, it seems appropriate to present the research as a coherent piece. By coherent we mean that, explicitly or implicitly, the correspondence between ontology, epistemology, and methodology is appropriately articulated (Guba \& Lincoln, 1994). Otherwise, the repeatability and comparability of the findings cannot easily be achieved, nor the relevance appropriately established.

Additionally, there is a need in our postmodern times to integrate findings in order to arrive at comprehensive approaches to explain complex problems and situations. The Integral Theory (Wilber, 2001, $2005,2007)$ is widely used in a number of fields: Medicine, Leadership, Political Sciences and Education, among many others (Wilber, 2005; Helfrich, 2007, 2008). To make possible scientific advances, Integral Theory needs at the same time to differentiate and to integrate (Wilber, 2001; Helfrich, 2008), which are two independent dimensions of complexity (Gallifa \& Botella, 2000). This can be done only after becoming aware of the ontological, epistemological and methodological backgrounds of the diverse findings.

The aim of this article is to review the most prominent research paradigms or epistemological traditions and their coherent correspondence with their respective ontologies and the corresponding methodological approaches. The purpose is to inform the use of research methods and techniques, providing their source of validity and relevance, as well as their interpretative framework. Although there have been some wellknown previous examinations of research paradigms (Guba \& Lincoln, 1994; Crotty, 1998; Creswell, 2007), it is a field that is open to refinement. In particular, we find it necessary to integrate the system of epistemology from the empirical-logical rationale and the one from the Aristotelian episteme. Additionally, the paradigms developed, in order to be truly comprehensive, have to be coherent with constructivist views and integral/holonic theories and rationales. A comprehensive framework of paradigms that meets these requirements has yet to be created.

The declared objectives of providing a rationale in order to make possible dialogue within a critical community, presenting coherent and suitable research, and applying an informed framework to contextualise this research, all come together here. Of course, the aim of most immediate interest to researchers and to this paper is to increase research quality. We hope that the detailed presentation of some distinct methodological frameworks will encourage the appropriate selection and justification of the research methods, as well as raise awareness of the use of mixed methods. The following points fall outside the scope of this paper:

- The diversity of available quantitative and qualitative methods and the rationales for their applicability.

- Sampling procedures and rationale.

- Discussion of data collection instruments: questionnaires, surveys (quantitative techniques) or in depth-interviews, focus groups, participant observation (qualitative techniques).

- The available instruments for data transcription or data processing.

- The ways to establish the validity and reliability of quantitative measures or to validate interpretive qualitative findings.

- The structure of the written report, oriented either to fill a knowledge gap or toward problem-solving. All these aspects are important and decisive elements of research design. Although making the right choices on these matters may be enough for a single piece of research, problems will arise at the moment of establishing the research's relevance and/or integrating it into a collective effort to advance knowledge in complex fields like the social sciences are. At that moment, the awareness of the research tradition is important and irreplaceable.

In this article, we will introduce the rationales for research traditions or paradigms and their corresponding methodologies. Methodologies are rationales that guide and inspire diverse methods of obtaining data. In a second part, we will briefly discuss the foundations of the research traditions that were studied in a previous work (Gallifa, 2018b). In a third part, we will introduce the four research traditions. For each one, we will describe the corresponding ontology, examine the appropriate and coherent methodological rationales, and look at the influence the tradition has had on social sciences research, particularly in Psychology and Education. For each tradition, ilustrative examples of methodologies will be provided, covering a wide and quite exhaustive range of possibilities. 


\section{Foundations of research traditions}

\section{Definition of research traditions or paradigms}

There are diverse research traditions in social sciences. Each tradition is a way to understand knowledge building and its validity. For the purposes of characterisation, three questions can be used to analyze research traditions or paradigms used to create knowledge (Guba \& Lincoln, 1994, p. 108):

- Ontological: What is the form and nature of reality and what is there that can be known about it?

- Epistemological: What is the nature of the relationship between the knower or would-be knower and what can be known?

- Methodological: How can the inquirer (would-be knower) go about finding out whatever he or she believes can be known?

Any given research tradition is expected to have coherent responses to these questions as a paradigmatic trait. Guba \& Lincoln (1994) defined paradigms as human constructions, composed of sets of basic beliefs. "They are not open to proofs in any conventional sense. Advocates in any particular construction must rely on persuasiveness and utility rather than proof in arguing their position" (Guba \& Lincoln, 1994, p. 108). In a previous paper (Gallifa, 2018a), we outlined some rationales to characterise research traditions and to help advance toward a solution to address what seemed their arbitrary character, as we will explain below.

Guba \& Lincoln (1994) advocated for four paradigms. In our case, we'll also consider four research traditions, following the rationales developed. The first two traditions are Logical Empiricism and Constructivism, defined in accordance with Guba \& Lincoln (1994), but the other two, Conceptualism and Phenomenology, will be defined a bit differently here, in correspondence with our alternative development (Gallifa, 2018b).

\section{Rationales for research traditions}

Following a phenomenological approach (Merleau Ponty, 1945) and a phenomenological methodology (Giorgi, 1997, 2012), Gallifa (2018b) developed four ways to substantiate four paradigms for knowledge building. The four paradigms characterised were: Empirical Logical Science, Constructivism, Conceptualism (or Productive Science in the Aristotelian tradition) and Phenomenology. The following table summarises the four rationales developed:
The approaches summarised can be understood as rationales for the different research traditions or paradigms, which serve to sustain them, and to come to an in-depth understanding of their foundations and differences.

It has to be noted that autopoiesis in the interior of the objective Wilber's quadrants (UR, LR) are not ways to create knowledge. In Wilber's model, these interiors are objective reality itself. Knowledge in these quadrants is only in the external dimension. On the other hand, Wilber proposed the social dimension from the interobjective quadrant (LR), as separated from the intersubjective (cultural, LL). These two dimensions seem difficult to view as separate, given their representational character (Harari, 2014). For that reason, in a previous work Gallifa (2018a) placed them in the same intersubjective (LL) quadrant, with social realities viewed as developmental lines resulting from cultural evolution in space-time. Returning to basics, the interobjective world was characterised as 'relationships' between objects. If objective knowledge corresponds to cognition, in the inter-objective quadrant the correspondence is with metacognition, and with strategic, tacit, practical knowledge (Brown, 1987, 1997). Gallifa (2018a) proposed a redefinition of the interobjective quadrant more in line with the Aristotelian tekhne. The change is aligned with Wilber's views that also included these relationships in this interobjective quadrant.

In light of this classification of Aristotelian, integral, holonic and constructivist ways of reasoning (Gallifa, $2018 b$ ), and of the considerations made, it is easy to observe coincidences and differences in the cited four traditions, which will be developed in the next part. The traditions according to Guba \& Lincoln (1994) can be named as paradigms or research traditions.

\section{Research traditions and corresponding methodologies}

\section{Logical empirical science}

The logical empirical paradigm has also been called the Galilean tradition (Spence, 1994) or positivism/neopositivism (Guba \& Lincoln, 1994). The ontology here is realism, which means that there is an external and objective reality (object-objectivity), separate from the subject that creates knowledge. The epistemology is founded on the view of the natural world as opaque. Repetition of observations is needed in order to iden-

Table 1. Foundations of the research traditions. Review of previous epistemological work (Gallifa, 2018b)

\begin{tabular}{|c|c|c|c|c|}
\hline Paradigm & Logical Empirical Science & Constructivism & $\begin{array}{l}\text { Conceptualism or Productive } \\
\text { Science }\end{array}$ & Phenomenology \\
\hline $\begin{array}{l}\text { Philosophical rationale: } \\
\text { Aristotelian epistemologies }\end{array}$ & Episteme theoretike & Epsiteme praktike, phronesis & Episteme poietike, tekhne & Nous \\
\hline $\begin{array}{l}\text { Wilber's Integral Theory } \\
\text { rationale }\end{array}$ & $\begin{array}{l}\text { Upper right quadrant - UR } \\
\text { (Objective behavior) } \\
\text { - Interior: Autopoyesis } \\
\text { - Exterior: Empiricism, } \\
\text { Behaviorism }\end{array}$ & $\begin{array}{l}\text { Lower left quadrant-LL } \\
\text { (Intersubjective cultural systems) } \\
\text { - Interior: Hermeneutics } \\
\text { - Exterior: Cultural Anthropology }\end{array}$ & $\begin{array}{l}\text { Lower right quadrant-LR } \\
\text { (Interobjective social systems) } \\
\text { - Interior: Social autopoyesis } \\
\text { - Exterior: Ecological Sciences, } \\
\text { Systems Theory, Anthropology }\end{array}$ & $\begin{array}{l}\text { Upper left quadrant UL } \\
\text { (Subjective intention) } \\
\text { - Interior: Introspection, } \\
\text { Phenomenology } \\
\text { - Exterior: Structuralism }\end{array}$ \\
\hline Holonic theory rationale & Immanence & Communion & Agency & Transcendence \\
\hline Constructivist rationale & Positivism and Neopositivism & Constructivism and Critical Theory & Pragmatism & Subjectivism \\
\hline
\end{tabular}


tify trends and inductively create hypotheses and theories. Logical deductive confrontation is also used to test theoretical consistency with the data (Popper). Changes of interest in scientific communities can be explained as paradigm shifts (Kuhn, 1970). Logical empiricism discarded the Aristotelian arguments from authority and relied on repetition of observations and criticism instead of on particular cases. In this tradition, the single case doesn't have wisdom (Spence, 1994). The methodology is observational and experimental, with the use of quantitative methods to characterise reality though measurements. Finally, the aim is the establishment of scientific laws that are relationships between variables or formulas. In Psychology, all the forms of Behaviorism, and also Psychometrics and Experimental Psychology, fall into this tradition.

Experimental/Observational methodologies: Quantitative methodology

Quantitative methods within an experimental/observational framework are used to test theoretical consistency and to propose new theories. The requirements in terms of methodological approach are: the need to start off from existing theories; the identification of a gap in knowledge and the use of observations, measurements, indexes and/or design experiments/observations to test the new hypothesis; and the construction of theories sustained by empirical data. This construction is open to criticism from new research. There are many methods available, and researchers may use a wide variety of them (Salvador \& Gallifa, 1997). An example of this methodological approach in educational research is the evidence-based education movement (Slavin, 2002, 2008), which is influencing many current school reforms.

Outside the scope of a single article is a description of the quantitative methodology, which is already present in the mainstream of the social science scientific writings. This lack of in-depth discussion in an article does not mean that the methodology is less important, nor that it is any less relevant to the advancement of knowledge.

\section{Constructivism}

Constructivism is a paradigm for knowledge construction. Guba \& Lincoln (1994) explained that this paradigm emerged at the same time as the evolution of social sciences in postmodernity, and was opposed to positivism and neo-positivism. In short, the ontology of the paradigm can be summarised by the belief that 'reality is a construction of the subject'. In other words, truth is relative and has only contextual validity. Laws are not nomothetic, but idiographic. Instead of the mechanistic metaphor of the previous paradigm, an organismic metaphor is preferred, with evolutionary reasoning incorporated. The relative character of the knowledge is a trait of the epistemology of this paradigm. The methods are qualitative or a mixture of quantitative and qualitative. Rationality and criticism are present, and the paradigm is consistent with postmodern worldviews.

Constructivism applies a wide diversity of methods that can be grouped under Hermeneutics or Ethnomethodology. Hermeneutics is the interpretation of experience and its meaning. Ethnomethodology comes from cultural anthropology and emic-etic visions (Harris, 1990) and sustains a wide range of methods. The methodological rationale in the constructivist paradigm favours the systematization and use of qualitative techniques (Creswell, 2007). The techniques applied are qualitative interviews, participant and non-participant observation, case studies, life stories, narrative, theme identification, repertory grids, etc.

\section{Discourse Analysis}

Starks \& Brown (2007) explain that the methodology of Discourse Analysis (DA) evolved from linguistic studies, literary criticism, and semiotics and is concerned with language-in-use; that is, how individuals accomplish personal, social, and political projects through language. Language mediates and constructs the understanding of reality and defines the social roles that are available to individuals and serves as the primary means through which they enact their identities (Starks \& Brown, 2007, p. 1374). Gee (2005) described the seven "building tasks" of language: significance, activities, identities, relationships, politics, connections, and sign systems and knowledge. Analyzing them can shed light on the creation and maintenance of social norms, the construction of personal and group identities, and the negotiation of social and political interaction (Starks \& Brown, 2007). The goal of discourse analysis is "to understand how people use language to create and enact identities and activities" (Starks \& Brown, 2007, p. 1373).

When employing a DA-based method, especially when there is an interest in the psychological aspects of the discourse, there are a number of steps to be followed (Goodman, 2017):

- Deciding on an appropriate question for Discourse Analysis. Before moving on to sources of data, there are some potential problems with choosing topics for analysis that need to be addressed. While discourse analysis can be used to effectively critique problematic patterns of speech, it can also be used to support speakers by understanding the arguments they make (Goodman, 2017, p. 145).

- Picking appropriate data sources for analysis. As DA is concerned with what is accomplished in interaction, the most appropriate sources of data are those that contain some kind of interaction. Data is also 'natural', as it will involve real people speaking in real social situations, who will be 'naturally' generating action orientated talk. This is true even if the social situation has been constructed/created for the sake of research.

- Generating a corpus of data. The criteria for including data in a corpus will depend upon the research question, so again it is important to be clear about 
exactly why particular data has been included for analysis (Goodman, 2017, p. 147).

- Transcribing the data. This can be one of the most time-consuming parts of the analysis. It is sometimes suggested that approximately ten minutes need to be allowed to analyse one minute's worth of talk. While this task may seem to be laborious, it is useful as it is an extremely good way of becoming familiar with the data, which means that the early stages of the analysis are being conducted during the transcription process. All transcripts should be line numbered so that the analyst can refer to specific parts of the data in the analysis.

- Preliminary reading/searching for the action orientation. It is necessary to read and re-read the data until the analyst becomes familiar with it. Exactly what to look out for at this stage will depend on the specific research question being addressed. It is worth noting that a whole range of action orientations are likely to be displayed in any data; this is to be expected, so it is important that the analyst focuses only on what is relevant to the research question at hand.

- Generating results/discursive devices and rhetorical/ interactional strategies. By this point, the analyst should have a good idea of what interesting action orientations seem to be occurring in the data, so it is now necessary to begin generating appropriate outcomes for a discursive analysis. Here, it is necessary to identify a number of discursive and rhetorical strategies that address the chosen research question. Specific strategies include: identifying interpretative repertories, ideological dilemmas, subject position, and identity.

- Building a case to support the findings. The analyst will need to pick the extracts that best illustrate the strategy being discussed and then describe them in detail. Each extract requires a description of the action orientation of what is being said in the talk, it is not enough to simply describe what is being said.

- Report writing. A discourse analysis write-up will begin with an abstract (which should written last), have an introduction section that provides context for the topic area, and a rationale for the research question. It is not the case that the literature review can only address discursive research, although it will almost certainly be necessary to refer to some. Next comes the method section which should include information about the specific type of discourse analysis used; data selection and collection; how the data was transcribed and how the strategies were identified. The next section contains the results. To complete the analysis, it should begin with a brief overview of the findings being discussed. The final section of a discourse analysis report is the discussion, which should include a brief overview of the findings; implications for the literature (both discursive and non-discursive); practical implications; limitations and suggestions for future research (Goodman, 2017, p. 151).
One modality of DA is Critical Discourse Analysis (CDA), which arises from a critical theory of language that sees the use of language as a form of social practice. "All social practices are tied to specific historical contexts and are the means by which existing social relations are reproduced or contested and different interests are served. It is the questions pertaining to interests (How is the text positioned or positioning? Whose interests are served by this positioning? Whose interests are negated? What are the consequences of this positioning?) that relate discourse to relations of power. Where analysis seeks to understand how discourse is implicated in relations of power, it is called Critical Discourse Analysis" (Janks, 1997).

Fairclough's (2013) model for CDA proposed three inter-related processes of analysis tied to three interrelated dimensions of discourse. These three dimensions are:

1. The object of analysis (including verbal, visual, or verbal and visual texts).

2. The processes by means of which the object is produced and received (writing/speaking/designing and reading/listening/viewing) by human subjects.

3. The socio-historical conditions which govern these processes.

According to Fairclough (2013) each of these dimensions respectively requires a different kind of analysis in a general process of DA:

1. Text analysis (description)

2. Processing analysis (interpretation)

3. Social analysis (explanation)

Critical Discourse Analysis has a long tradition in Education (Rogers, 2004).

Whether a researcher opts for DA or CDA, "high quality" research using the content analysis should consider the following concepts and categories: words, terms, themes, characters, items, time-space, appearance, frequency, intensity and subject matter. In addition, within the concept of subject matter, the research can evaluate the following concepts: standard, values, methods, traits, actors, authority, origins, location and time, conflicts, and endings. Good Discourse Analysis requires a detailed and focused description of the action(s) that are performed by the strategies identified. "It is a focus on action that makes for a good analysis. Other features of a high-quality analysis include a good selection of extracts, drawn from an appropriate corpus of data and a good demonstration of familiarity with related and relevant discursive strategies" (Goodman, 2017, p. 151).

\section{Ethnomethodology}

Ethnographic research examines shared patterns of behaviour, beliefs, and language in cultural groups. Diverse subtypes of ethnography have been developed, each with its own different theoretical orientations and aims: "structural functionalism, symbolic interactionism, cultural and cognitive anthropology, feminism, Marxism, ethnomethodology, critical theory, cultural studies and postmodernism" (Creswell, 2007, p. 69). 
Two main forms have emerged (Creswell, 2007, p. 70):

- The realist approach, which consists of an objective account of the situations typically written by the researcher in third-person, who reports the "facts" and remains in the background. This form was characterised by Van Maanen (1988).

- The critical approach, which includes an advocacy perspective in the research in response to current society, where various systems serve to marginalise individuals of different classes, ethnic origins or gender. In this case, researchers advocate for the emancipation of groups who are marginalised by the system (Thomas, 1993). For example, critical ethnographers can study schools that provide privileges to a certain type of students or counselling practices that neglect the needs of underrepresented groups.

There is no single way of conducting Ethnography, but some common procedures may include the following steps (Creswell, 2007, pp. 71-72):

- Appropriateness of ethnography, determining which is the appropriate methodology when there is a need to describe how a cultural group functions and to explore beliefs, language, behaviours, and issues such as power, resistance, and dominance.

- Identification and location of the culture-sharing group to be studied.

- Selection of the cultural themes or issues to study about the group. This may include topics such as enculturation, socialization, learning, cognition, domination, inequality or child or adult development. The ethnographer begins the study by examining people's interactions in ordinary settings and attempting to discern pervasive patterns such as lifecycles, events, and cultural themes. The group's history, religion, politics, economy and environment, within the social structure, kinship, political structure, and social relations among members of the group may be described.

- Study of cultural concepts, using a particular ethnographic approach, whether realist or critical.

- Fieldwork. Gathering of information about where the group works and/or lives. A range of kinds of data can be obtained, using diverse techniques. The time for data collection is extensive, involving prolonged time in the field. Participatory observation and description of patterns or topics of the group's culture are different activities. Research issues like respecting people, reciprocity, deciding who owns the data, and ethics in all research aspects are central.

- Final product. Narrative writing. Holistic cultural portrait of the group that incorporates the views of participants (emic) and the views of the researcher (etic). Final report incorporates a particular style (realist or critical).

\section{Conceptualism, productive science}

Tekhne, in the conceptualization of Aristotle, is the episteme oriented to the poiesis. More than one possible creative solution is possible. Tekhnes can be denominated as productive or applied sciences or simply arts (from the Latin ars) (Gallifa, 2018a). An example is tekhne retorike, the art of eloquence and persuasiveness. Therefore, the interobjective epistemological dimension can be called Aristotelian applied or productive science. Spence refers to it as the Aristotelian tradition, or the conceptualist way of building knowledge (Spence, 1994).

The Aristotelian tradition was predominant in premodern traditions in medieval Europe. It was pervasive in scholastics, where the seven major arts (trivium and quadrivium) organised curricula in the flourishing newborn universities. The main point of this episteme is that nature is completely intelligible. The 'form' reveals the essence. There is no distinctiveness (hylemorphism) between them. However, only certain trained observers can see the essence in the form. When the discovery is made, truth is self-evident. A favourite case (specimen) represents the discovery (Spence, 1994). There is a reliance on the authoritative sources from a given tradition.

The ontology at work here was creationism (a creator-creature relationship, similar to the artist-artefact relationship). The general methodology of the doctrine of signatures helped to create a tradition in a particular episteme. The doctrine of signatures was popular in the Renaissance and was discredited by Bacon and his emphasis on empiricism (Spence, 1994). In this way of constructing knowledge, the nature of things is none other than their appearance. This appearance is only visible in a network of signs. The following steps can be taken to obtain knowledge (Spence, 1994):

- Determination of the Aristotelian categories (substance, quality, quantity...)

- To find out the truthful essence using similitudes (convenience, emulation, analogy, and sympathy) between two realities: one well known and other unknown. Similitudes help in projecting knowledge from the known reality to the unknown.

This methodology helps to create traditions of knowledge. It works like a "guild", in which the novel apprentice is integrated to learn from the previously established authority. Spence considered Freudian Psychoanalysis to be an example of Aristotelian episteme poietike or Conceptualist Science (Spence, 1994).

\section{Design-Based Research}

Design-Based Research (DBR) (Van den Akker et al., 2006) is a type of research based on a systematic process of analysis, design, development, and evaluation of an intervention (a training program, a product or a process) as a solution to a complex educational problem (Plomp \& Nieveen, 2009). The characteristics of DBR, following the contributions of different authors, can be defined using a number of points (Reeves, Herrington \& Oliver, 2002; Reeves, McKenney \& Herrington, 2011):

- Focuses on complex problems in real contexts. 
- Involves intensive collaboration between researchers and practitioners.

- Integrates recognised and hypothetical design principles to provide solutions to complex problems, but ones that are possible to solve.

- Allows for the carrying out of rigorous and reflective studies to experiment and to create better innovative learning environments, as well as to define new design principles.

- Requires long-term involvement to make possible continuous improvement of protocols and issues.

- Maintains commitment to theory building, to the extension of the theory and to the resolution of problems in the real world.

At the same time, DBR follows three principles. The research is:

- Recursive (iterative): iteration means a design and developmental process that allows the practitioners and experts to participate, in a complementary way, to the revision and reformulation of the process.

- Reflective: assumes that most of the problems in the professional practice can't be solved with preconceived solutions.

- Participative: reflects a change in perspective by considering the expert, the researcher, and the designer as part of the same team with similar responsibilities throughout the stages of the research process.

DBR is considered a mixed and dynamic methodology, as there are decisions taken prior to research and others that are taken during the research process. This explains why some methodological specifications cannot be defined or explained "a priori". DBR is not defined by the methods it uses, but by the objective that it pursues, which is sustained innovation (Bereiter, 2002). The research process through DBR is structured in phases and has a cyclical nature (McKenney, 2001). Next, we will define the different phases:

- Preliminary phase: the research problem and the characteristics of the context are analysed at the same time as a consistent conceptual framework is developed based on a thorough review of the literature and on the real needs of the context to be studied.

- Prototype phase: where a prototype of the intervention (program or product) is designed, developed and reviewed. These three steps are repeated cyclically. Thanks to this process, a more advanced and more complex prototype is progressively achieved.

- Evaluation phase: the effectiveness of the intervention is analysed. The principles of the design are documented and described.

Nieveen (1999) states that in order to guarantee quality in the application of a DBR methodology, four criteria must be taken into account: relevance (validity of content), consistency (construction validity), feasibility or functionality (practicality) and efficacy (effectiveness). In order to achieve the four, it is necessary to define the corresponding mechanisms and verification strategies.

\section{Phenomenology}

Phenomenology is the study of phenomena and their essences. Phenomenology is distinct in that it studies 'lived experience', which is how we immediately engage with a given phenomenon or aspect of human life (van Manen, 1990). The assumption is that we can only understand the world through our conscious awareness and experience of it. Sometimes, Phenomenology is considered a methodology or a single method within the constructivist paradigm. We consider Phenomenology not only as a methodology but also as a paradigm (Gallifa, 2018b).

Phenomenology was originated by Husserl, who sought to discover a methodology to find truth or essence without following the path and corresponding worldview of conventional science. Some mental habits of researchers are the result of their training inside the modern "scaffolding" (Toulmin, 1990), leading to research influenced by the prevailing categories of science. The problem is the implicit 'modern' science implicitly finds it difficult to study the subject and subjective phenomena, as well as to study consciousness. This happens because of the prevalence of the declared positivist commitment to rejecting any kind of introspection.

Merleau Ponty systematised this alternative process for knowledge creation (Merleau Ponty, 1945). According to this author, Phenomenology is based on four interrelated processes. He described these overlapping steps for a phenomenological study:

- Description: the process of constructing a narrative of the studied phenomena. The phenomenologist researcher gathers new data and returns time after time to the description of the phenomena, which is becoming richer and more complete each time that it is described.

- Phenomenological reduction: the commitment not to complete the research too quickly to come to a final theory. Instead, there is a need to wait and to resist the temptation to make quick theoretical interpretations to explain the phenomena. This practice is a self-imposed limitation, because of the scientific bias in the mind of the researcher. It is highly necessary to return to description and to limit interpretation and the application of existing theories. This reduction is made in order to respect the phenomena, which have to be manifested as purely as can be, without simplifications.

- Eidetic reduction: this is the search for essence, the aim of any phenomenological method. This phase requires the use of imagination and symbolic capabilities. It is the moment when the discovery is made. Sometimes, all the data fit into an idea, an intuition or a vision. When this occurs, there emerges a self-evident reality.

- Intentionality: an aspect of consciousness. The transcendental subject, not the individual subject, once the previous points have been developed, is manifested in the researcher's consciousness. The 
phenomenological path allows the manifestation of the transcendental dimension of the consciousness, which is an objective reality. This means that transcendence of existing theories and models is possible, as well as the objective character of the findings.

When these four characteristics are present, we will consider the corresponding approach to belong to the phenomenological tradition or paradigm. Fully phenomenological methodologies are very different from the constructivist approaches, the latter with their manifest lack of concern for objective knowledge. That distinction is important and has been underestimated by some, possibly because some qualitative researchers share the common postmodern worldview and its characteristic relative lack of concern about objectivity.

\section{Applied Phenomenology}

A distinction can be made between Phenomenology as a philosophical method whose 'object' is the consciousness of the transcendental subject, and Phenomenology as a method available to any field of knowledge. Giorgi (2012) developed a phenomenological method for psychological research on humans (Giorgi, 2012). He explained that psychologically phenomenologists are interested specifically in human consciousness, and because of that limited interest, the phenomenological method needs to be pretranscendental. Psychology, in effect, is interested in how a human consciousness relates to a specifically human world. (Giorgi, 2012). Van den Berg emphasised that "insights into experience as lived, or the phenomenal level, was what was critical for psychologists to understand" (Giorgi, 2015, p. 141). "The criteria necessary in order for a qualitative scientific method to qualify itself as phenomenological in a descriptive Husserlian sense, one would have to employ (1) description (2) within the attitude of the phenomenological reduction, and (3) seek the most invariant meanings for a context" (Giorgi, 1997, p. 235). This kind of minimization of the general phenomenological approach can be labelled as Applied Phenomenology. "In Applied Phenomenology reality is comprehended through embodied experience. Through close examination of individual experiences, phenomenological analysts seek to capture the meaning and common features, or essences, of an experience or event. The truth of the event, as an abstract entity, is subjective and knowable only through embodied perception; we create meaning through the experience of moving through space and across time" (Starks \& Brown, 2007, 1374).

Phenomenology as a methodology sometimes is situated inside the Constructivist paradigm. Nevertheless, when there is intentionality of the consciousness acting, the applied phenomenological approach accomplishes the four phases of the general HusserlianMerleau Ponty method, and for that reason it is understood to belong to the phenomenological research paradigm (Gallifa, 2018b).
An example of Applied Phenomenology in Psychoanalysis is the Psychology of Jung $(1968,1993)$. Hostie (1957) recovered Jungian Psychology for Phenomenology, after explaining the problems involved in considering Freudian Psychoanalysis a phenomenological based methodology.

\section{Grounded Theory}

Another example of a phenomenologically inspired method is Grounded Theory. We will present it and at the same time justify why we consider it to be phenomenological. Grounded theory didn't come directly from Phenomenology, but its methodological path meets the phenomenological minimum requirements for Applied Phenomenology, and when it is well implemented it can be considered a phenomenological methodology. Grounded Theory methods emerged from the collaboration of the sociologists Glaser and Strauss during the 1960s. Glaser and Strauss (1967) challenged "the arbitrary division of theory and research; the prevailing view of qualitative research as primarily a precursor to more 'rigorous' quantitative methods by claiming the legitimacy of qualitative work in its own right; the belief that qualitative methods were impressionistic and unsystematic; the separation of data collection and analysis phases of research; and the assumption that qualitative research only produced descriptive case-studies rather than theory development. They articulated explicit analytic procedures and research strategies that previously had remained implicit among qualitative researchers" (Charmaz, 1996, p. 29). "Grounded theory originates from Sociology, specifically from Symbolic Interactionism, which posits that meaning is negotiated and understood through interactions with others in social processes. These social processes have structures, implied or explicit codes of conduct, and procedures that circumscribe how interactions unfold and shape the meaning that comes from them" (Starks \& Brown, 2007, p. 1374). "Glaser and Strauss portray their methods as compatible with traditional positivistic assumptions of an external reality that researchers can discover and record" (Charmaz, 1996, p. 30). This separates Grounded Theory from Constructivism.

"Grounded Theory is a general methodology for developing theory grounded in data, systematically gathered and analyzed. Theory evolves during actual research, and it does this as a continuous interplay between analysis and data collection. A central feature of this analytic approach is 'a general method of [constant] comparative analysis'” (Glasser \& Strauss, 1967, vii), hence "the approach is often referred to as the constant comparative method" (Strauss \& Corbin, 1994, p. 273). "Theory consists of 'plausible' relationships proposed among concepts and sets of concepts (Though only plausible, its plausibility is to be strengthened through continued research)" (Strauss \& Corbin, 1994, p. 278). "They do not believe it sufficient merely to report or give voice to the viewpoints of the people, groups or organizations studied. Researchers 
assume the further responsibility of interpreting what is observed, heard, or read" (Strauss \& Corbin, 1994, p. 276). "Explicit mandate to strive toward verification of its resulting hypotheses (statements of relationships between concepts). This is done throughout the curse of a research project, rather than assuming that verification is possible only through follow-up quantitative research. Enhanced also by its procedures is the possibility of developing theory of great conceptual density and with considerable meaningful variation. Conceptual density refers to richness of concept development and relationships -which rest on great familiarity with associated data and are checked out systematically with these data" (Strauss \& Corbin, 1994, p. 276). Researchers in psychology, anthropology, and education are increasingly using grounded theory procedures.

"Theories are interpretations made from given perspectives as adopted or researched by researchers. To say that a given theory is an interpretation -and therefore fallible- is not at all to deny that judgments can be made about the soundness or probable usefulness of it. All interpretations, whether or not they have the features or status of theory, are temporally limitedin a dual sense. First, they are always provisional; second, like many other kinds of knowledge, theories are limited in time: Researchers and theorists are not gods, but men and women living in certain eras, immersed in certain societies, subject to current ideas and ideologies, and so forth. Hence as conditions change at any level of the conditional matrix, this affects the validity of theories -that is, their relation to contemporary social reality. Theories are constantly becoming outdated or in need of qualification" (Strauss \& Corbin, 1994, p. 279). In short "theories are embedded 'in history' -historical epochs, eras, and moments are to be taken into account in the creation, judgment, revision, and reformulation of theories" (Strauss \& Corbin, 1994, p. 280).

Grounded theory methods (Charmaz, 1996 and Strauss \& Corbin, 1994) include the following steps:

- Simultaneous involvement in data collection and analysis phases of research. Grounded theory works are empirical based studies, whether their data sources are autobiographies, published accounts, public records, novels, intensive interviews, casestudies, participant-observer field notes or personal journals.

- Creation of analytic codes and categories developed from data, not from preconceived hypotheses; Computer software (e.g., NUD.IST or ATLAS/ti) can be useful in categorization processes.

- Development of middle-range theories to explain behavior and processes. Constant comparison, repeated comparison of segments of data within and across cases, asking questions, looking for negative or disconfirming cases, 'flip/flopping' concepts, metaphors and similes, waving the 'red flag'.

- Memo-making, that is, writing analytic notes to explicate and fill out categories, the crucial inter- mediate step between coding data and writing first drafts. Types of memos: Defining codes and open data exploration, identifying and developing concepts, asking questions about the data, working out relationships among concepts, refining and adjusting data collection or operations of analysis and integrating concepts or summarizing.

- Theoretical sampling: sampling for theory construction, not for representativeness of a given population, to check and refine the analyst's emerging conceptual categories.

- Delay of the literature review (Charmaz, 1996, p. 28). As a result, "the empiricism inherent in grounded theory methods makes them less congenial to those postmodernists who advocate abandoning empirical research with thinking, feeling, acting human beings. These postmodernists may, however, be amenable to studying pre-established texts" (Charmaz, 1996, p. 31). "A grounded theory analysis starts with data and remains close to the data. Levels of abstraction are built directly upon the data and are checked and refined by gathering further data" (Charmaz, 1996, p. 28).

"Insofar as theory that is developed through this methodology is able to specify consequences and their related conditions, the theorist can claim predictability for it, in the limited sense that if elsewhere approximately similar conditions obtain, the approximately similar consequences should occur" (Strauss \& Corbin, 1994, p. 278). A study is more phenomenological in the following cases: if it does not culminate in a definitive theory, returns to data description, uses intuition, reflections about memos, but especially if the conditions of the interaction (time, space) are part of the analysis. In that case, transcendence and profundity increases and the phenomenological transcendental function operates as a manifestation of the intention of consciousness.

Grounded Theory methodology has a long tradition in education, as Hutchinson (1988) reported. Interestingly enough, these pioneering studies shared the Husserlian orientation, similarly to the development presented here.

\section{Conclusions}

\section{Research traditions}

We have reviewed and explored four research traditions or paradigms in the social sciences. For each one, we have introduced the ontological, epistemological and methodological correspondences. We have presented examples of methodologies for each paradigm in order to show specific examples of the theoretical approaches to determining how to obtain data. The four paradigms are:

1. Logical empirical science

2. Constructivism

3. Conceptualism or Aristotelian productive science

4. Phenomenology 
Table 2. Paradigms or research traditions. Adapted from Gallifa (2018b)

\begin{tabular}{|c|c|c|c|c|}
\hline Paradigms & Logical Empirical Science & Constructivism & $\begin{array}{l}\text { Conceptualism or Productive } \\
\text { Science }\end{array}$ & Phenomenology \\
\hline Epistemology & Episteme theoretike & Episteme praktike, phronesis & Episteme poietike, tekhne & Nous \\
\hline Ontology & $\begin{array}{l}\text { Realism. } \\
\text { Mechanicism }\end{array}$ & $\begin{array}{l}\text { Reality constructed by the } \\
\text { subject. Organicism }\end{array}$ & $\begin{array}{l}\text { Creationism artist-artifact. } \\
\text { Authority within a tradition }\end{array}$ & $\begin{array}{l}\text { Essence and intentionality of } \\
\text { consciousness. Holism and } \\
\text { integralism }\end{array}$ \\
\hline Methodology & $\begin{array}{l}\text { Experimental and } \\
\text { Observational }\end{array}$ & $\begin{array}{l}\text { Hermeneutical and } \\
\text { Anthropological }\end{array}$ & Conceptualist and Design-Based & $\begin{array}{l}\text { Phenomenological and } \\
\text { Structuralist }\end{array}$ \\
\hline $\begin{array}{l}\text { Examples of } \\
\text { methodologies }\end{array}$ & Evidence-Based Research & $\begin{array}{l}\text { Discourse Analysis and } \\
\text { Ethnomethodology }\end{array}$ & Design-Based Research & $\begin{array}{l}\text { Applied Phenomenology and } \\
\text { Grounded Theory }\end{array}$ \\
\hline
\end{tabular}

These traditions can be considered meta-paradigmatic. Within each one there are a number of concrete paradigms, normal science (Kuhn, 1970), methodologies, methods, and particular techniques. Additionally, these traditions cover the Aristotelian ways of constructing knowledge (Gallifa, 2018b): Episteme (Logical Empirical, extended to a range of branches of conventional science), the relation with praxis, oriented to phronesis and related with human behaviour (Constructivism), the tekhne with orientation to poiesis (Productive or Conceptualist sciences or Arts) and the nous (approached by Phenomenology). Together they constitute the Sophia, or wisdom.

The corresponding ontologies to each of the traditions were also discussed. Logical empiricist ontology would correspond to realism and mechanicism (sciences from Modernity), Constructivism corresponds to relativism and organicism (sciences in Postmodernity), Pragmatism corresponds to applied sciences and the "authority" within a tradition (premodern epistemes), and Phenomenology corresponds to holism and integralism (the emerging current worldview).

\section{Methodologies}

The ways of creating knowledge, once the meta-paradigms are established, have to be coherent with each ontology and epistemology. We have presented the rationale of the methodologies and some details. Corresponding to each epistemological tradition, the methodologies are:

1. Experimental and Observational (Logical empiricism)

2. Hermeneutical and Anthropological (Constructivism)

3. Conceptualist and Design-Based (Aristotelian episteme tekhne)

4. Phenomenological and Structuralist (Phenomenology)

The table above summarises the comparison between traditions, as has been explained (table 2).

We are not advocating for one methodology or another. We have explained why all of them are valuable and rational ways to obtain knowledge in the social sciences. There are no "good" or "bad", "better" or "worse", methodologies in the abstract. It would be more appropriate to focus our attention on "good" and "bad" (pure/mixed) methodologies by considering their suitability to sustaining methods for particular pieces of research.

\section{Final remark}

There is a need for coherence between methodology, ontology, and epistemology in today's research projects examining complex problems or phenomena. To achieve these aims, it seems indispensable to have a degree of awareness of the research traditions presented here. When this awareness is appropriately and explicitly stated, it will be an those seeking to produce quality, impactful research.

\section{References}

Bereiter, C. (2002). Design Research for Sustained Innovation. Cognitive Studies, 9(3), 321-327.

Brown, A. L. (1987). Metacognition, executive control, self-regulation, and other more mysterious mechanisms. New Jersey: Lawrence Erlbaum Associates.

Brown, A. L. (1997). Transforming schools into communities of thinking and learning about serious matters. The American Psychologist, 52(4), 399-413.

Charmaz, K. (1996). Grounded theory. In J. A. Smith, R. Harré, \& L. Van Langenhove (Eds.). Rethinking methods in psychology (pp. 27-49). London: Sage Publications.

Creswell, J. W. (2007). Five qualitative approaches to inquiry. In J. W. Creswell \& C. N. Poth (eds.), Qualitative Inquiry and Research Design: Choosing Among the Five Traditions (pp. 53-84). Thousand Oaks, CA: Sage Publications.

Crotty, M. (1998). The foundations of social research: Meaning and perspective in the research process. London: Sage.

Fairclough, N. (2013). Critical discourse analysis. In R. Wodak (Ed.). London: Sage.

Gallifa, J. (2018a). The Tekhne-logic revolution. Rethinking the 'interobjective' dimension of the Integral Theory. Consequences and relevance to Education. Creative Education, 9(7), 1084-1104.

Gallifa, J. (2018b). Paradigms for knowledge building. Review of Educational Theory, 1(3), 70-81.

Gallifa, J. \& Botella, L. (2000) The Structural Quadrants Method: A new approach to the Assessment of Construct System Complexity vía Repertory Grid. Journal of Constructivist Psychology, 13(1), 1-26.

Gee, J. P. (2005). An introduction to discourse analysis: Theory and method ( $2^{\text {nd }}$ ed.). London: Routledge.

Giorgi, A. (1997). The Theory, Practice, and Evaluation of the Phenomenological Method as a Qualitative Research Procedure. Journal of Phenomenological Psychology, 28(2), 235-260. 
Giorgi, A. (2012). The Descriptive Phenomenological Psychological Method. Journal of Phenomenological Psychology, 43(1), 3 - 12.

Giorgi, A. (2015). The Phenomenological Psychology of J.H. van den Berg. Journal of Phenomenological Psychology, 46(2), 141-162.

Glaser, B. G., \& Strauss, A. L. (1967). Discovery of grounded theory: Strategies for qualitative research. London: Aldine Transaction.

Goodman, S. (2017). How to conduct a psychological discourse analysis. Critical Approaches to Discourse Analysis Across Disciplines, 9(2), 142-153.

Guba, E. G., \& Lincoln, Y. S. (1994). Competing paradigms in qualitative research. In N. K. Denzin, \& Y. S. Lincoln (eds.) Handbook of Qualitative Research (pp. 105-117). Thousand Oaks, California: Sage.

Harari, Y. N. (2014). Sapiens: A Brief History of Humankind. New York: Random House.

Harris, M. (1990). Antropología Cultural. Madrid: Alianza Editorial.

Helfrich, P. M. (2007). Ken Wilber's model of human development. An overview. Retrieved from: http://www. paulhelfrich.com/library/Helfrich_P_The_Five_Phases_of_Wilber.pdf

Helfrich, P. M. (2008). Ken Wilber's AQAL metatheory: An overview. Castaic, CA: Wildfire Media.

Hostie, R. (1957). Religion and the psychology of Jung. London: Sheed \& Ward.

Hutchinson, S. A. (1988). Education and Grounded Theory. In R. R. Sherman \& R. B. Webb (eds.), Qualitative Research in Education: Focus and Methods (pp.122-139). London: Falmer Press.

Janks, H. (1997). Critical discourse analysis as a research tool. Discourse: studies in the cultural politics of education, 18(3), 329-342.

Jung, C.G. (1968) Analítical psychology: its theory and practice: the Tavistock lectures. New York: Vintage books.

Jung, C.G. (1993) The basic writings of C.G. Jung. New York: The Modern Library.

Kuhn, T. S. (1970). The Structure of Scientific Revolutions (2nd enl. Ed). Chicago IL: University of Chicago Press.

McKenney, S. (2001). Computer-based support for science education materials developers in Africa: Exploring potentials (Unpublished doctoral dissertation). University of Twente, Enschede.

Merleau Ponty, M. (1945). Phénoménologie de la perception. París: Gallimard.

Nieveen, N. (1999). Prototyping to reach product quality. En Dalam J. Van Den Akker, et al (Eds.). Design approaches and tools in education and training. London: Kluwer academic publishers.

Plomp, T. \& Nieveen, N. (2009). An introduction to educational design research. Enschede, the Netherlands:
Netherlands Institute for curriculum development (SLO).

Reeves, T.C., Herrington, J. \& Oliver, R. (2002). Authentic activities and online learning. In: HERDSA 2002 Quality Conversations, 7 - 10 July 2002, Perth, Western Australia. pp. 562-567.

Reeves, T. C., McKenney, S., \& Herrington, J. (2011). Publishing and perishing: The critical importance of educational design research. Australasian Journal of Educational Technology, 27(1), 55-65.

Rogers, R. (2004). An introduction to critical discourse analysis in education. In $A n$ introduction to critical discourse analysis in education (pp. 31-48). London: Routledge.

Salvador, F. \& Gallifa, J. (1997). Introducció al disseny d'experiments en Psicologia. Col.lecció Biblioteca Universitària. Fundació Enciclopèdia Catalana.

Slavin, R. E. (2002). Evidence-based education policies: Transforming educational practice and research. Educational researcher, 31(7), 15-21.

Slavin, R. E. (2008). Perspectives on evidence-based research in education-what works? Issues in synthesizing educational program evaluations. Educational Researcher, 37(1), 5-14.

Spence, D. (1994). The Rhetorical Voice of Psychoanalysis. Displacement of Evidence by Theory. Cambridge MA: Harvard University Press.

Starks, H. \& Brown, T. S. (2007). Choose your method: A comparison of phenomenology, discourse analysis, and grounded theory. Qualitative health research, 17(10), 1372-1380.

Strauss, A., \& Corbin, J. (1994). Grounded theory methodology: An overview. In N. K. Denzin \& Y.S. Lincoln, Handbook of qualitative research (pp. 273285). London: Sage publications.

Thomas, J. (1993). Doing critical ethnography. London: Sage publications.

Toulmin, S. E. (1990). Cosmopolis: the hidden agenda of modernity. New York: Free Press.

Van den Akker, J., Gravemeijer, K., McKenney, S., \& Nieveen, N. (Eds.). (2006). Educational design research. Routledge.

Van Maanen, J. (1988). Tales of the Field: On Writing Ethnography. Chicago: University of Chicago Press.

van Manen, M. (1990). Researching lived experience: Human science for an action sensitive pedagogy. Albany: State University of New York Press.

Wilber, K. (2001). The theory of everything. Boston, MA: Shambhala.

Wilber, K. (2005). Introduction to Integral Theory and Practice IOS basic and the AQAL map. AQAL Journal of Integral Theory and Practice, 1(1), 1-38.

Wilber, K. (2007). The integral vision: A very short introduction. Boston, MA: Shambhala. 